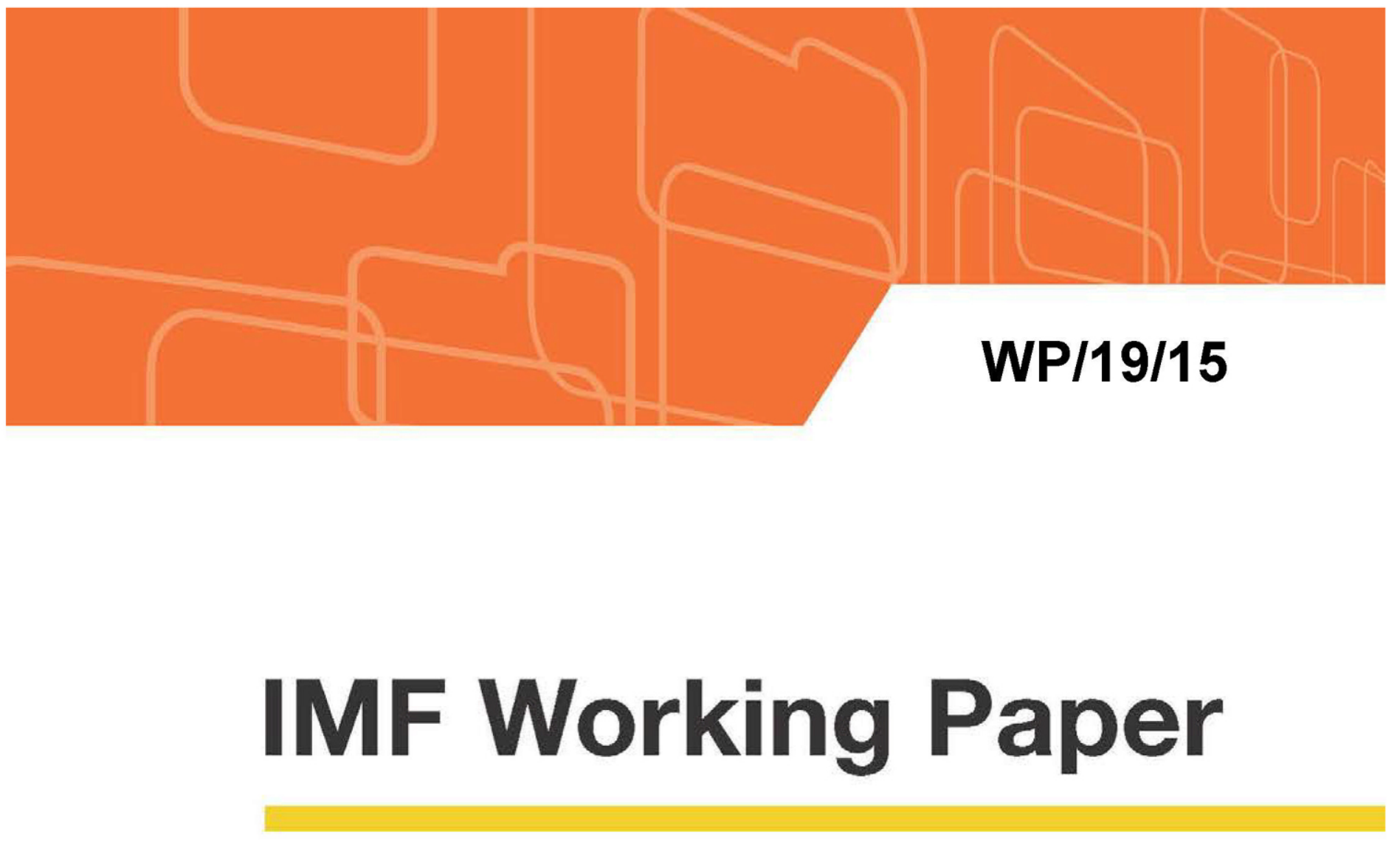

\title{
Gross National Happiness and Macroeconomic Indicators in the Kingdom of Bhutan
}

by Sriram Balasubramanian and Paul Cashin

IMF Working Papers describe research in progress by the author(s) and are published to elicit comments and to encourage debate. The views expressed in IMF Working Papers are those of the author(s) and do not necessarily represent the views of the IMF, its Executive Board, or IMF management. 


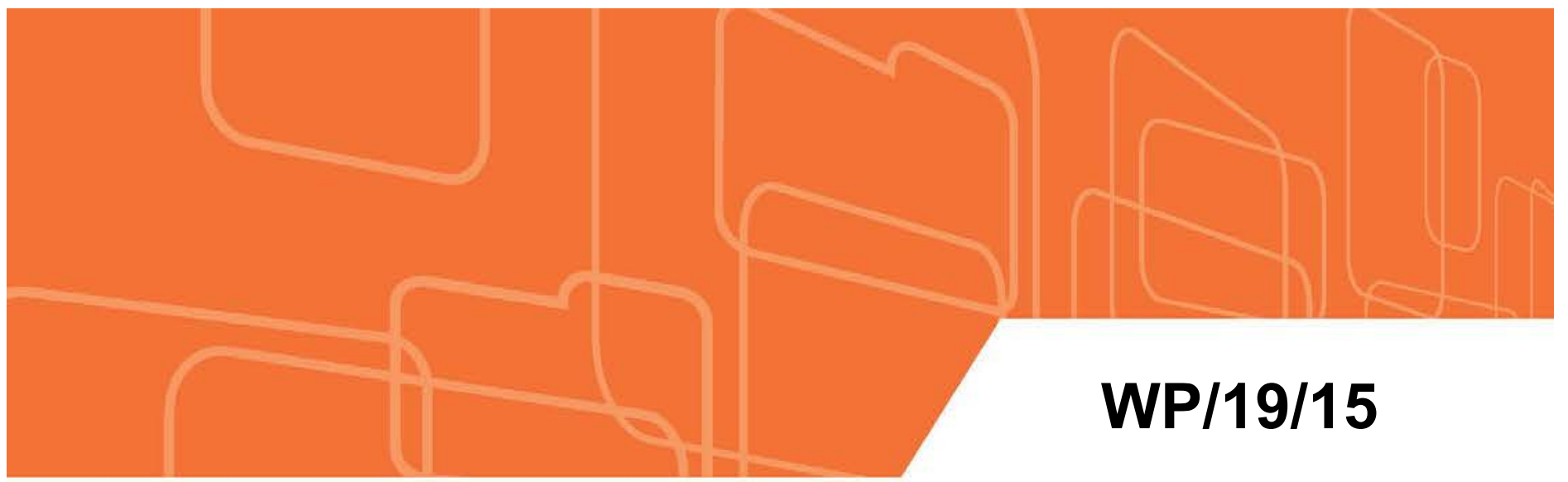

\title{
IMF Working Paper
}

\section{Gross National Happiness and Macroeconomic Indicators in the Kingdom of Bhutan}

\author{
by Sriram Balasubramanian and Paul Cashin
}

IMF Working Papers describe research in progress by the author(s) and are published to elicit comments and to encourage debate. The views expressed in IMF Working Papers are those of the author(s) and do not necessarily represent the views of the IMF, its Executive Board, or IMF management. 


\title{
IMF Working Paper
}

Asia and Pacific Department

\section{Gross National Happiness and Macroeconomic Indicators in the Kingdom of Bhutan Prepared by Sriram Balasubramanian and Paul Cashin ${ }^{1}$}

January 2019

\section{IMF Working Papers describe research in progress by the author(s) and are published to elicit comments and to encourage debate. The views expressed in IMF Working Papers are those of the author(s) and do not necessarily represent the views of the IMF, its Executive Board, or IMF management.}

\begin{abstract}
This paper examines the origins and use of the concept of Gross National Happiness (or subjective well-being) in the Kingdom of Bhutan, and the relationship between measured well-being and macroeconomic indicators. While there are only a few national surveys of Gross National Happiness in Bhutan, the concept has been used to guide public policymaking for the country's various Five-Year Plans. Consistent with the Easterlin Paradox, available evidence indicates that Bhutan's rapid increase in national income is only weakly associated with increases in measured levels of well-being. It will be important for Bhutan to undertake more frequent Gross National Happiness surveys and evaluations, to better build evidence for comovement of well-being and macroeconomic concepts such as real national income.
\end{abstract}

JEL Classification Numbers: D63, I3, O1

Keywords: real income, gross national happiness, gross domestic product, Bhutan

Authors’ E-Mail Addresses: sriramb@worldbank.org and pcashin@imf.org

\footnotetext{
${ }^{1}$ The authors are Consultant Economist at the International Finance Corporation and Assistant Director in the IMF's Asia Pacific Department, respectively. This research began while Sriram Balasubramanian was working in the office of the IMF Executive Director for Bhutan, India, Sri Lanka, and Bangladesh — he thanks Dr Subir Gokarn (IMF Executive Director) and his office for providing encouragement and support for this exercise. The authors also thank David Gregorian, Rakesh Gupta, Purva Khera, Xavier Maret, Racha Moussa, and Anh Le for helpful comments and data analysis, and Professor Akbar Noman, Professor Eugene McGill, and the capstone team from Columbia University's School of International and Public Affairs for their inputs. Most of all, the authors are grateful to Bhutan's Office of the Prime Minister and the Center for Bhutan Studies (Dr Pema Kinley) for providing both moral and informative support to facilitate this work.
} 
Abstract

I. Introduction $\underline{3}$

II. Role of GNH and GDP in Policymaking and Development $\underline{5}$

III. Easterlin Paradox $\underline{7}$

IV. Gross National Happiness: Philosophy and Background $\underline{9}$

V. GDP Growth and GNH Policies $\underline{15}$

VI. Evaluating Comovement of GNH and GDP $\underline{19}$

VII. Conclusion $\underline{21}$

References

\section{FIGURES}

1. Government Structure in Bhutan

2. Pillars, Domains and Indicators of GNH 2016

3. Bhutan: Real GDP per capita 1980-2017

4. Bhutan: Recent Macroeconomic Developments 15

5. Bhutan: Macroeconomic Developments 1980-2017 19

TABLES

1. World Happiness Rankings 2017, 2018 $\underline{8}$

2. Bhutan: Details of the Nine Domains of Gross National Happiness 12

3. Sample of GNH Survey Results, 2010 and 2015 14

4. Bhutan: GDP Sector Shares and Growth Rates, 1980-89 $\underline{16}$ 


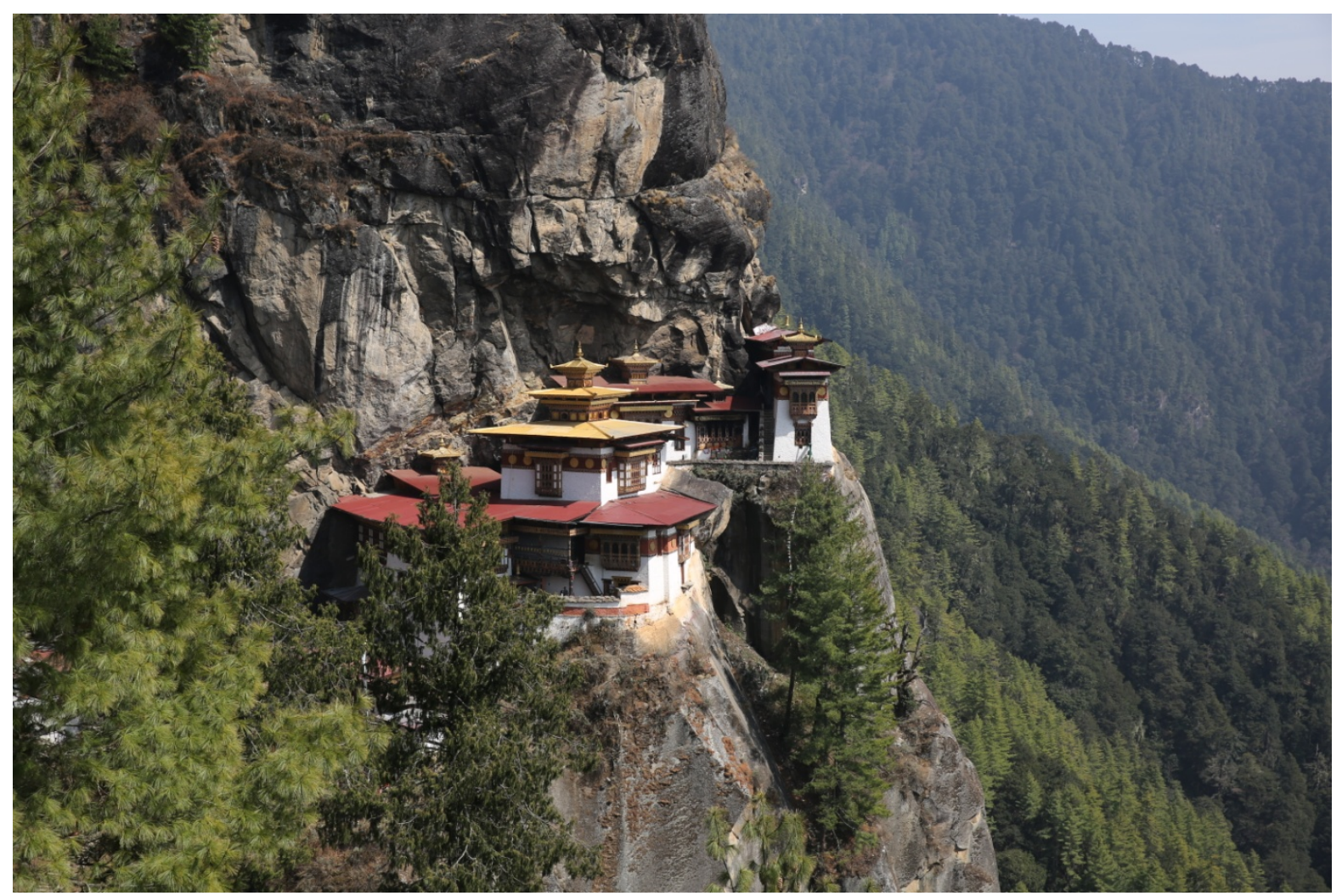

\section{INTRODUCTION}

Bhutan is a unique country in terms of both its geography and form of economic development. Bhutan is a small country located in the eastern Himalayas between India and the People's Republic of China. According to the 2017 Census, Bhutan is home to a population of about 735,000 people (National Statistics Bureau, 2018). It was ruled by a popular monarchy until 2008, when the monarchy decided to make Bhutan a democratic state to ensure that the people had a voice in running their future. Integral to the Bhutanese ethos and philosophy is their belief in Vajrayana Buddhism (Dorji, 1991) which has formed the pivot for the country's progress for many centuries. At the core of this philosophy are the key components of compassion and respect for all, and for the government to take care of its citizens.

The economics of Bhutan is driven largely by three key industries - hydroelectric power, tourism and agriculture - and Bhutan enjoys large trade connections with India, which has been a key supporter of Bhutan over the years. There has been significant progress in the 
level of real per capita GDP, growing from about US\$400 in 1980 to about US\$2,800 in 2016, with Bhutan now nearing middle-income status (see IMF, 2018). ${ }^{2}$

\section{Gross National Happiness (GNH) as a multi-dimensional development approach}

The most important element of the Bhutanese model of development has been the concept of Gross National Happiness (GNH), and the GNH index and tool which has been formulated alongside this philosophy. GNH was in Bhutan in 1972 by the Fourth King of Bhutan, Jigme Singhye Wangchuk, the father of the current king, Jigme Khesar Namgyel Wangchuck (see Government of Bhutan, 2015). He declared that "Gross National Happiness is more important than Gross Domestic Product". The King had envisioned an economic development model which was based on the tenets of Buddhist philosophy and holistic development, which had its core functions preserving the environment and emphasizing the role of happiness and collective well-being in the lives of people. This emphasis on happiness was to override the role of monetary incomes which was at the heart of the GDPdriven global development model. With assistance from international organizations and bilateral development partners, the government also incorporated major development related issues into its agenda such as sustainability, climate change and inequality. ${ }^{4}$

While GNH has evolved over time, in its quest to stay relevant, the role of GDP in Bhutan has also changed through the years. In the decades of the 1980s and 1990s, GDP was primarily used as a tool for Bhutan's financial indicators and as a benchmark for access to international grants and loans from multilateral agencies. Even though publicly the primacy of GNH is being advocated by Bhutan, GDP measurements have thus also played a substantive role in the country's development.

In this context, this paper will look at the relationship between the evolution of GNH and the evolution of GDP and other macroeconomic indicators. The paper also aims to see if there is co-movement between the two concepts, and will discuss whether there is a need to balance both GDP and GNH in a more holistic economic model that may serve as a complementary tool to be used in future by developing and developed countries. Using the case of Bhutan, this paper will examine the relationship between GDP growth and happiness (or well-being), using subjective well-being measures such as surveys of nationally-representative samples of the population (such as the GNH Surveys). That is, we will examine whether GDP growth is a useful proxy for and conduit to happiness, and whether happiness-driven policies can help raise economic growth rates.

The rest of the paper is structured as follows. Section II contains a discussion of the roles of GNH and GDP in Bhutanese policymaking and measurement of development. Section III provides a brief overview of the Easterlin Paradox of the relationship between happiness and real output. Section IV looks at the underpinnings of GNH philosophy, describes the

\footnotetext{
${ }^{2}$ Since its introduction in 1974, the Bhutanese ngultrum has been pegged to the Indian rupee at par. The Bhutan fiscal year begins July 1 , and the macroeconomic data described in this paper is on a calendar year basis (for example, the entry for $2012 / 13$ is for 2012).

${ }^{3}$ GDP per capita (constant 2010 U.S. dollars) are from World Bank, World Development Indicators database.

${ }^{4}$ The Constitution of Bhutan in Article 9 directs the state "to promote those conditions that will enable the pursuit of Gross National Happiness".
} 
structure of the major indicators underpinning the GNH framework, and sets out the GNH survey results. The evolving relationship between GNH policies and real GDP growth is detailed in Section V, and the extent of any co-movement between GNH and GDP is evaluated in Section VI. Section VII concludes.

\section{Role OF GNH AND GDP IN POLICYMAKING AND DEVElopment}

The GNH Commission (GNHC) plays a pivotal role in assessing projects through the lens of the GNH tool (the four pillars of GNH being an integral part of the tool) and ensures that there is a seamless inclusion of GNH at almost all levels of governmental functioning within Bhutan $^{5}$. GNH is incorporated within the country's Five Year Plans (FYP), and the planning processes extend all the way to the small local levels in the respective dzonkhags (administrative and judicial districts) and gewogs (residential blocks). Since the Tenth FYP, there has been a results-based approach framework which has been adopted where each of the performance in the individual sectors and across sixteen national key result areas are mapped to the four pillars of GNH. In April 2012, as an extension of international efforts led by the United Nations (UN) to measure sustainable development goals (SDG), GNH was discussed as a new global economic paradigm on the sidelines of the United Nations General Assembly meetings. Furthermore, the UN also declared the following year 'The International Day of Happiness' on March 20 ${ }^{\text {th }}$. The developments in GNH have been cognizant of the SDG's, and have incorporated policies to be in alignment with the SDG goals set by the UN for Bhutan.

The mainstreaming of GNH has been orchestrated through the Bhutanese policymaking process (as shown in Figure 1 below). As part of this process, individual agencies within the government formulate a concept note that will be submitted to Cabinet for its consideration. This concept note is subsequently run through the GNHC Secretary who evaluates the note and the extent of its adherence to the GNH framework, using the GNH tool and its indicators as a reference point. Based on the suggestions provided by the GNHC Secretary, an updated draft note is then formulated. This updated draft is evaluated by a group of 15 members from a wide range of stakeholders across Bhutanese ministries and industries. Each of these stakeholders will give a score of 1-4 for the 22 variables which are present in the PST. Based on these scores, the note is then passed onto the GNHC Committee and eventually the Cabinet for approval. Once the approval is completed, there is a plan which is set in motion for the implementation of the concerned policies. ${ }^{6}$ The approval is finalized for these projects following the approval of the above mentioned PAC for implementation by the government (see Columbia University, 2016).

The GNH index draws upon the vision of development as it has evolved in Bhutan. The GNH index is used to: set an alternative framework of development; provide indicators to sectors to guide development; help policy design and the allocation of public resources; and

\footnotetext{
${ }^{5}$ These pillars are detailed further in Figure 2. The four pillars are: sustainable and equitable social economic development; preservation and promotion of culture; conservation of environment; and good governance.

${ }^{6}$ In addition to the above processes, projects which are worth more than US\$5000 need to go through another GNHC Internal Project Appraisal Committee (PAC), which evaluates them one more time based on another 18 indicators.
} 
measure well-being and happiness, both over time and cross-sectionally for the regions of Bhutan (see Government of Bhutan, 2015).

The planning, monitoring and evaluation of these projects (which have been cleared by the GNHC and Cabinet) takes place at a continuous level through the lifecycle of these projects. Based on the nature of the project, there are weekly, quarterly and bi-annual levels of assessment of these projects. While these protocols are in place, the evaluation process for individual projects is still an area which needs to be improved upon. This overall structure represents the macro view of how governance functions in Bhutan. It is in this context that one also needs to look at the role of Gross Domestic Product and its historical context in Bhutan.

\section{Figure 1: Government Structure in Bhutan}

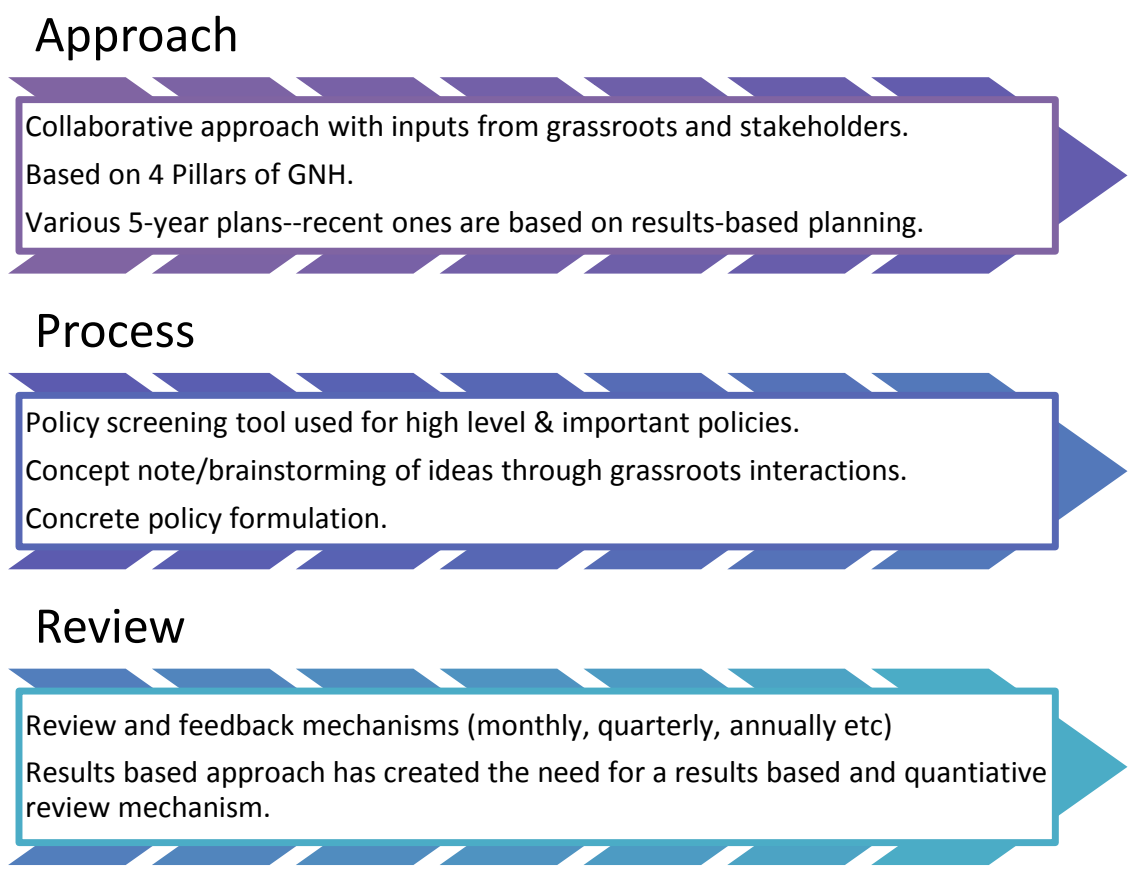

Source: Columbia University (2016).

\section{GDP and its role in development}

GDP is a standard benchmark to measure economic growth and in turn prosperity in most countries of the world. GDP is designed (and clearly acknowledged by its compilers) as a measure of the level of economic activity rather than welfare, and hence excludes many dimensions of economic activity that affect welfare, including the distribution of income and wealth, household production, the use and destruction of the natural environment, and inequality in economic opportunity. It also omits many other important determinants of wellbeing, such as governance, security, health, and longevity.

In the case of Bhutan, the concept of GDP plays a secondary role in the measuring national well-being, especially after 1972 when GNH was formally introduced to the world. The focus has been on developing GNH and its broader philosophical outreach in a modern world 
of which Bhutan is increasingly becoming part. This broader narrative of GNH has often been seen to be a competitor to the concept of GDP in popular parlance. While there is importance given to GNH in Bhutan, governmental organizations (especially commerce related ones) focus keen attention on GDP and how it measures trade, commerce and the economic prosperity of the country. In addition, the IMF has provided a great deal of technical assistance to Bhutan to help improve its national accounts (see International Monetary Fund, 2018).

Bhutan's rate of economic growth (as measured by real GDP) has been rapid. As shown in Figure 5, in 2017 Bhutan's real GDP had reached Nu64.8 billion, while in 1980 it was only Nu4.6 billion ${ }^{7}$. There has been consistent growth in real GDP in Bhutan every decade. In 1990, real GDP was Nu11.8 billion (a 156 percent increase since 1980), in 2000 real GDP was Nu19.2 billion (a 62 percent increase since 1990), and in 2010 real GDP was Nu43.04 billion (a 124 percent increase since 2000).

These GDP figures indicate that there has been an upward trend in real GDP over the years. More importantly, it also indicates that the government is not ignoring GDP-related data in their governance and growth. Despite the overarching influence of GNH, GDP plays a pivotal role for the commerce ministry, economic affairs and other sectors including the private sector. It is important to note that prevalence of GNH through the government and developmental processes has not necessarily resulted in a lowering of GDP growth over the years. Finally, analysis of the comovement of GNH and GDP measures will present another opportunity to discuss the uniqueness of Bhutan's GNH-based economic and administrative model.

\section{EASTERLin PARADox}

One of the most important and controversial issues in the literature on happiness (or subjective well-being) is whether growth in national income is always associated with higher well-being (see Government of Bhutan, 2015). In a famous article, Easterlin (1974, revised in 1995) asked whether "raising the incomes of all will raise the happiness of all?" This was based on the observation that reported happiness levels remained flat over the long-run in countries which had experienced high rates of real income growth — the Easterlin Paradox.

An extrapolation of this observation to the top 10 countries in the rankings of the World Happiness Report 2018 further reiterates its relevance:

\footnotetext{
${ }^{7}$ Real GDP (constant 2000/2001 Bhutanese ngultrum) are from IMF, World Economic Outlook data.
} 
Table 1. World Happiness Rankings 2017, 2018

\begin{tabular}{|c|c|c|c|c|c|c|c|c|}
\hline \multicolumn{2}{|c|}{$\begin{array}{c}2017 \text { World Happiness } \\
\text { Rankings (based on 2014-16 } \\
\text { happiness scores) }\end{array}$} & \multicolumn{2}{|c|}{$\begin{array}{c}2018 \text { World Happiness } \\
\text { Rankings (based on 2015-17 } \\
\text { happiness scores) }\end{array}$} & \multirow{2}{*}{$\begin{array}{l}\text { Happiness } \\
\text { Scores } \\
\text { Difference } \\
2017-18\end{array}$} & \multirow{2}{*}{$\begin{array}{l}\text { Happiness } \\
\text { Rankings } \\
\text { Difference } \\
\text { 2017-18 }\end{array}$} & \multirow{2}{*}{$\begin{array}{l}2016 \\
\text { Real } \\
\text { GDP } \\
\text { per } \\
\text { capita } \\
\text { U.S. } \\
\text { Dollars }\end{array}$} & \multirow{2}{*}{$\begin{array}{l}2017 \\
\text { Real } \\
\text { GDP } \\
\text { per } \\
\text { capita } \\
\text { U.S. } \\
\text { Dollars }\end{array}$} & \multirow{2}{*}{$\begin{array}{c}\text { Real GDP } \\
\text { per capita } \\
\text { Difference } \\
\begin{array}{c}\text { U.S. } \\
\text { Dollars }\end{array}\end{array}$} \\
\hline $\begin{array}{l}\text { Country } \\
\text { Rankings } \\
1-10\end{array}$ & $\begin{array}{l}\text { Happiness } \\
\text { Scores } \\
1-10\end{array}$ & $\begin{array}{l}\text { Country } \\
\text { Rankings } \\
1-10\end{array}$ & $\begin{array}{l}\text { Happiness } \\
\text { Scores } \\
1-10\end{array}$ & & & & & \\
\hline 1. Norway & 7.537 & 1. Finland & 7.632 & 0.163 & 4 & 43,514 & 46,016 & 2,502 \\
\hline 2. Denmark & 7.522 & 2. Norway & 7.594 & 0.057 & -1 & 70,651 & 74,940 & 4,288 \\
\hline 3. Iceland & 7.504 & 3. Denmark & 7.555 & 0.033 & -1 & 53,773 & 56,444 & 2,670 \\
\hline 4. Switzerland & 7.494 & 4. Iceland & 7.495 & -0.009 & -1 & 60,392 & 70,332 & 9,939 \\
\hline 5. Finland & 7.469 & 5. Switzerland & 7.487 & -0.007 & -1 & 80,310 & 80,590 & 280 \\
\hline 6. Netherlands & 7.377 & 6. Netherlands & 7.441 & 0.064 & 0 & 45,657 & 48,345 & 2,688 \\
\hline 7. Canada & 7.316 & 7. Canada & 7.328 & 0.012 & 0 & 42,418 & 45,077 & 2,658 \\
\hline 8. New Zealand & 7.314 & 8. New Zealand & 7.324 & 0.01 & 0 & 39,050 & 41,593 & 2,542 \\
\hline 9. Australia & 7.284 & 9. Sweden & 7.314 & 0.03 & 1 & 51,470 & 53,217 & 1,746 \\
\hline 10. Sweden & 7.284 & 10. Australia & 7.272 & -0.012 & -1 & 51,872 & 55,707 & 3,834 \\
\hline $\begin{array}{l}\text { 14. United States } \\
\text { of America }\end{array}$ & 6.993 & $\begin{array}{l}\text { 18. United States } \\
\text { of America }\end{array}$ & 6.886 & -0.107 & -8 & 57,558 & 59,501 & 1,942 \\
\hline 97. Bhutan & 5.011 & 97. Bhutan & 5.082 & 0.071 & 0 & 2,824 & 2,969 & 145 \\
\hline
\end{tabular}

Source: Helliwell et al. (2018).

The change in the World Happiness Scores of the top 10 countries in the Happiness Rankings-Happiness Scores Difference (2017-18), according to the Easterlin Paradox (ceteris paribus), should not be proportional to the change in the top 10 rankings of national Real GDP per capita (year-on-year difference). If it is indeed not proportional, it would reaffirm the notion that the country with the highest Happiness score is not necessarily the one with the highest per capita GDP. There might also be declining returns to happiness, and so happiness does not necessarily grow linearly with income over a given timeframe.

As can be seen in Table 1, the Easterlin Paradox is confirmed for some of these countries in the table (see Helliwell et al., 2018). It is also important to note that this holds when a similar analysis/comparsion with World Happiness Scores vs Happiness Rankings-Rankings Difference (2017-18) is undertaken as well.

The real GDP per capita of countries such as Iceland, Switzerland and Australia have all increased in 2017 compared to 2016, yet their corresponding Happiness scores for 2018 visà-vis 2017 have fallen, thus making them 'less happy' during this time period. Also, while the real GDP per capita of countries such as Norway, Denmark, Iceland, Switzerland, and Australia all increased in 2017 compared to 2016, all these countries had a drop in their Happiness rankings, thus becoming 'less happy' during this period of time. Happiness rankings and scores for the United States vis-à-vis real GDP per capita changes provide a similar perspective.

Uniquely, the United States has seen a drop in its World Happiness score from 6.993 to 6.886 and a drop in its Happiness Ranking from $14^{\text {th }}$ place (in 2017) to $18^{\text {th }}$ place (in 2018), despite having an increase in real GDP per capita during the 2016-17 period. While a fall in the 
Happiness score is not frequent, historical records suggest that there has been barely any movement in U.S. Happiness scores despite large increases in real GDP per capita. As argued in the Chapter titled 'America's Health Crisis and the Easterlin Paradox' in the World Happiness Report 2018, since 1972 U.S. per capita income has more than doubled, yet there has been barely any movement in its happiness indices (see Helliwell et al., 2018). This has been largely attributed to the reduction in America's social capital and the fact that "...certain non-income determinants of U.S. happiness are worsening alongside the rise in U.S. per capita income, thereby offsetting the gains in subjective well-being that would normally arise with economic growth". These non-income factors include population health (measured by health-adjusted life expectancy); the strength of social support networks; personal freedom (measured by the perceived freedom of individuals to make key life decisions); social trust (measured by the public's perception of corruption in government and business); and generosity.

As an additional example of the Easterlin Paradox, this is indeed what we observe in the case of Bhutan. Despite real GDP per capita having multiplied by about six hundred percent over an almost forty-year period (1980-2017), the average happiness score of Bhutanese has only very modestly increased.

A key aspect of the growth-happiness paradox concerns the magnitude of the correlation coefficient and its statistical significance. A number of authors have underlined that there is less statistical power in long-run series of well-being than in the cross-section, due to the smaller standard deviation (Clark and Senik, 2011). This is certainly what we observe in the case of Bhutan. Two important explanations for the flatness of the growth-happiness curve have been posited: (i) the nature of growth itself, whereby growth is often accompanied by negative externalities, including increased pollution and inequality, that weigh against growth's subjective benefits (which include greater income and consumption); and (ii) psychological processes (including concerns over relative incomes) that may reduce the happiness flowing from absolute income growth and greater wealth accumulation.

\section{Gross National Happiness: Philosophy ANd BaCKGRound}

The GNH paradigm and its philosophy has its roots in the Vajrayana Buddhist philosophy, which the Bhutanese have been following for centuries (Dorji, 1991). According to the Center for Bhutan Studies, the premier agency that oversees research on GNH in Bhutan, the concept of GNH and the primary collective goal of happiness and well-being started in Bhutan as early as the $17^{\text {th }}$ Century with the arrival of Shabdrung Ngawang Namgyal from Tibet. The Buddhist monk played a significant role in shaping the subsequent cultural and sociological narrative in Bhutan. In line with new developmental models rising to prominence around the world, Bhutan was starting to undergo change in the early 1970s. It was then that the Fourth King stepped in and re-initiated the concept of GNH in an institutionalized format within government, so that it became an integral part of governance in Bhutan.

Over the years, Bhutan has evolved the GNH into a more holistic model which encompasses the local values of Bhutan with new developmental ideas and strategies of the modern world. The integration of external and internal ideas has provided Bhutan with an ideal template that 
can address key global issues such as climate change, sustainable development goals and the inequality perpetrated due to globalization in developing countries. This template, which was initially a philosophical and doctrinal world view, was institutionalized within a robust framework via a plethora of indicators included in the GNH index. This framework provided a more robust understanding to the rest of the world of the ideas that Bhutan was developing and using in its policymaking. In addition, it also enabled Bhutan to inculcate happiness as a policy tool within its governance framework.

In October 2009, the third OECD World Forum considered policies that focused on happiness instead of economic growth. In April 2012, GNH was discussed as a new global economic paradigm on the sidelines of the United Nations General Assembly. In the same year the UN also declared March 20th the "International Day of Happiness". The UN meeting was called to support growing efforts to create a new economic paradigm with the goal of bettering human well-being, building on Bhutan's nascent approach, which aims not just for GDP growth but for gains in GNH. Since then, GNH has featured more frequently in discussions on alternative development measures around the world, both contributing to and benefitting from international exchange, dialogues and insights.

\section{Description of Gross National Happiness}

The Royal Government of Bhutan in 2005 made the decision to develop GNH indicators to move the concept of GNH from an academic notion to a measurable one. The indicators aim to check whether programs and policies are consistent with the values of GNH. The government intended to create conditions for policymakers and citizens to be better informed, by taking appropriate measures for actual implementation of GNH policies and programs.

To establish the baseline indicators, the Centre for Bhutan Studies developed a detailed questionnaire covering the nine key areas (or domains) considered crucial for reflecting the values and principles of GNH. These key areas of GNH fall within the domains of psychological wellbeing, health, time use, education, culture, good governance, ecological resilience, community vitality and living standards.

The current GNH model (involving pillars, domains, and indicators) is defined as in Figure 2 below. 
Figure 2. Pillars, Domains and Indicators of GNH 2016

\begin{tabular}{|c|c|c|c|c|}
\hline Pillars & Domains & Indicators & & \\
\hline $\begin{array}{l}\text { Sustainable and Equitable } \\
\text { Social and Economic } \\
\text { Development }\end{array}$ & $\begin{array}{ll}\text { - } & \text { Living Standards } \\
\text { - } & \text { Education } \\
\text { - } & \text { Health }\end{array}$ & $\begin{array}{ll}\text { - } & \text { Per capita } \\
\text { income } \\
\text { - } & \text { Assets } \\
\text { - } & \text { Housing }\end{array}$ & $\begin{array}{ll}\text { - } & \text { Literacy } \\
\text { - } & \text { Schooling } \\
\text { - } & \text { Knowledge } \\
\text { - } & \text { Value }\end{array}$ & $\begin{array}{ll}\text { - } & \text { Self reported } \\
& \text { health } \\
\text { - } & \text { Healthy days } \\
\text { - } & \text { Disability } \\
\text { - } & \text { Mental Health }\end{array}$ \\
\hline $\begin{array}{l}\text { Preservation and Promotion } \\
\text { of Culture }\end{array}$ & $\begin{array}{ll}\text { - } & \text { Cultural Diversity } \\
\text { and Resilience } \\
\text { - } & \text { Community } \\
\text { Vitality } \\
\text { - } & \text { Time Use } \\
\text { - } & \text { Psychological } \\
& \text { well-being }\end{array}$ & $\begin{array}{ll}\text { - } & \text { Zoring Chusum } \\
& \text { Skills } \\
\text { - } & \text { Cultural } \\
& \text { Participation } \\
- & \text { Speaking native } \\
& \text { language }\end{array}$ & $\begin{array}{ll}\text { - } & \text { Donation } \\
\text { - } & \text { Safety } \\
\text { - } & \text { Community } \\
& \text { Relationship } \\
\text { - } & \text { Family }\end{array}$ & $\begin{array}{ll}\text { - } & \text { Life satisfaction } \\
\text { - } & \text { Positive emotions } \\
\text { - } & \text { Negative emotions } \\
\text { - } & \text { Spirituality }\end{array}$ \\
\hline $\begin{array}{l}\text { Conservation of } \\
\text { Environment }\end{array}$ & Ecological Diversity & -Wildlife damage & $\begin{array}{l}\text {-Urban Issues } \\
\text { - Responsibility towards } \\
\text { environment }\end{array}$ & -Ecological issues \\
\hline Good Governance & Good governance & 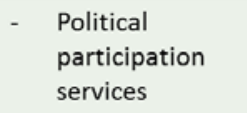 & - Fundamental Rights & $\begin{array}{l}\text { - Governance } \\
\text { performance }\end{array}$ \\
\hline
\end{tabular}

Sources: Centre for Bhutan Studies; Columbia University (2016).

There are 4 pillars, 9 domains and 33 indicators which are the key tenets that encompass the broader GNH framework. The 4 pillars include sustainable and equitable social, economic development; preservation and promotion of culture; conservation of environment; and good governance. Each of these four pillars as seen in Figure 2, are assigned to nine individual domains and then to a set of 33 indicators corresponding to the domains and the pillars. The overall GNH index is aggregated from the 33 grouped indicators, which are themselves comprised of 124 variables (each with their own indicator weights).

The nine domains can be further segregated and defined as shown in Table 2. 
Table 2. Bhutan: Details of the Nine Domains of Gross National Happiness

\begin{tabular}{|c|c|}
\hline Domains & Definition \\
\hline Living Standards & $\begin{array}{l}\text { Level of material comfort as measured by } \\
\text { income, conditions of financial security, } \\
\text { housing and asset ownership. }\end{array}$ \\
\hline Education & $\begin{array}{l}\text { Knowledge, values, skills and formal and } \\
\text { informal education across age levels. }\end{array}$ \\
\hline Health & $\begin{array}{l}\text { Condition of human body and mind to have } \\
\text { a holistic healthily lifestyle both at the } \\
\text { mental and physical states. }\end{array}$ \\
\hline Cultural Diversity and Resilience & $\begin{array}{l}\text { Strength and diversity of cultural norms, } \\
\text { ethos and festivals across the country and } \\
\text { age groups. }\end{array}$ \\
\hline Community Vitality & $\begin{array}{l}\text { Attempts to focus on the strengths and } \\
\text { weaknesses of relationships and interaction } \\
\text { within communities. It gathers information } \\
\text { on social cohesion among family members } \\
\text { and neighbors, and on practices like } \\
\text { volunteering. }\end{array}$ \\
\hline Time Use & Harmonious work life balance. \\
\hline Psychological well-being & $\begin{array}{l}\text { These living standards include spirituality, } \\
\text { reflective cognitive evaluations such as life } \\
\text { satisfaction, and affective reactions to life } \\
\text { events such as positive and negative } \\
\text { emotions. }\end{array}$ \\
\hline Ecological Diversity & $\begin{array}{l}\text { Measure's people's perceptions and } \\
\text { evaluations of the environmental conditions } \\
\text { of their neighborhood and assess eco- } \\
\text { friendly behavior pattern. }\end{array}$ \\
\hline Good Governance & $\begin{array}{l}\text { Evaluates the level of participation in } \\
\text { government decisions at the local level and } \\
\text { the presence of various rights and freedom. } \\
\text { It also assesses the level of efficacy, honesty } \\
\text { and quality within government. }\end{array}$ \\
\hline
\end{tabular}

Sources: Centre for Bhutan Studies; Columbia University (2016). 


\section{GNH Surveys and GNH Evolution}

The GNH surveys are an integral part of understanding the evolution of Bhutan's concept of GNH and its relevance to the people of the country. The surveys have been conducted in 2007-08, 2010 and 2015 respectively.

Following improvements in the questionnaire, the Centre for Bhutan Studies carried out the first Gross National Happiness survey in December 2007. The survey questionnaire included about 750 variables which are objective, subjective, and open-ended in nature. This survey was carried out only in 12 districts with a sample size of 950 persons: Dagana, Tsirang, Wangdiphodrang, Samtse, Zhemgang, Pemagatshel, Samdrupjongkhar, Trashigang, Tashiyangtse, Gasa, Haa and Thimphu. While an overall GNH index was computed from the data, it was not considered valid for any statistical analysis due to its limited sample size and the fact that it was representative nationally but not by district.

The 2010 GNH survey started in April 2010 and ended in December 2010, taking nearly 9 months to complete. In terms of survey coverage, the sample size was 7142 respondents with fully completed questionnaires and covered all 20 dzongkhags (districts) and almost all the gewogs (residential blocks). The 2010 GNH survey is nationally representative and representative at the district level, as well as covering rural and urban parts of the country (see Government of Bhutan, 2010).

Both the 2010 and later 2015 surveys covered almost 250 indicators across all 20 districts of Bhutan, and involved interviews with participants across sexes, ages, rural and urban areas, and occupation groups. The similarity of questions across these surveys is a significant benchmark to enable comparisons.

To measure GNH, a profile is created for each person showing in which of 33 grouped indicators (formed from the abovementioned 124 indicator variables) the person has achieved sufficiency. As noted by the Gross National Happiness Commission (2015), not all people need to be sufficient in each of the 124 variables to be happy. Accordingly, in tabulating the Survey results the Commission divides Bhutanese into four groups depending on their degree of happiness, using three cutoffs: $50 \%, 66 \%$ and $77 \%$. Bhutanese who have achieved sufficiency in less than 50 percent of the 124 variables are categorized as 'unhappy'; those who have sufficiency in 50-65\% of domains are categorized as 'narrowly happy'; a group categorized as 'extensively happy' have achieved sufficiency in 66-76\% of domains; while the 'deeply happy' have achieved sufficiency in $77 \%$ or more of the weighted indicators (that is, equivalent to seven of the nine domains) - also see Table 3.

In the construction of the overall GNH index, the GNH cutoff is set at $66 \%$ of the variables, the median cutoff as described above. People can therefore be described as happy if they are in either of the 'deeply happy' or 'extensively happy' categories. The 2015 results for example show about $43 \%$ of Bhutanese have achieved such happiness, while the remaining $56 \%$ are either 'narrowly happy' or 'unhappy'. For the preceding $2010 \mathrm{GNH}$ survey, the corresponding numbers were $37 \%$ and $63 \%$, respectively. Those in the 'narrowly happy' and 'unhappy' categories are considered as not-yet-happy for policy purposes. The GNH index ranges from zero to one, and a higher number is better. 
As noted in Government of Bhutan $(2015,2010)$, some of the highlights of the 2015 and earlier Surveys are:

$>$ The overall happiness levels had improved in comparison to the previous surveys. They decreased in 14 out of the 33 indicators from 2010 to 2015 and ratings increased across 12 indicators (with strongly positive changes), making a positive overall change in measured GNH. Other indicators did not show any change at all.

$>$ In the 2015 Survey, some 51 percent of men are 'happy' or 'extremely happy', compared with only 39 percent of women. Similarly, some 55 percent of urban dwellers are 'happy' or 'extremely happy', compared with only 38 percent of those living in rural areas. Among occupations, farmers were found to be the least happy.

The sectors which showed the largest improvement are services, ecological and housing, among others.

$>$ The indicators that show a significant decrease occuring in self-reported health, community relationships, Driglam Namzha, spirituality, fundamental rights, and negative emotions, and all four indicators of psychological well-being.

Overall there was a small but statistically significant increase in happiness between 2010 and 2015: the GNH index increased by $1.7 \%$, from 0.743 in 2010 to 0.756 in 2015.

Table 3. Sample of GNH Survey Results, 2010 and 2015

\begin{tabular}{|l|l|l|l|l|}
\hline $\begin{array}{l}\text { GNH } \\
\text { Surveys }\end{array}$ & $\begin{array}{l}\text { Score Range } \\
\mathbf{( \% )} \\
2015\end{array}$ & $\begin{array}{l}\text { Percentage of } \\
\text { people who are: } \\
(\%) 2015\end{array}$ & $\begin{array}{l}\text { Score Range } \\
(\%) \\
2010\end{array}$ & $\begin{array}{l}\text { Percentage of } \\
\text { people who are: } \\
(\%) 2010\end{array}$ \\
\hline Deeply Happy & $77-100$ & 8.4 & $77-100$ & 8.3 \\
\hline $\begin{array}{l}\text { Extensively } \\
\text { Happy }\end{array}$ & $66-76$ & 35.0 & $66-76$ & 32.6 \\
\hline Narrowly Happy & $50-65$ & 47.9 & $50-65$ & 48.7 \\
\hline Unhappy & $0-49$ & 8.8 & $0-49$ & 10.4 \\
\hline
\end{tabular}

Source: Centre for Bhutan Studies.

In other global happiness surveys, and particularly the World Happiness Report 2018, the happiness ranking of Bhutan fell from $84^{\text {th }}(2013-15)$ in the world to $97^{\text {th }}(2015-17)$ out of 156 countries. Accordingly, while on a global standard Bhutan's happiness is not that high, within Bhutan its self-reported happiness consistently keeps to a high standard (see Helliwell et al 2018). 


\section{GDP GROWTH AND GNH POLICIES}

It is interesting to note the evolution of real GDP in Bhutan over recent decades, especially during the concurrent changes in the GNH landscape and within the Bhutanese government and society at large. GDP is an important concept in Bhutan, especially in the economic ministries and central bank, as a key reference point for measurement of well-being in the country. International organizations have also accumulated reliable data that can substantiate and re-iterate the changes in GDP over the years. These changes could provide us with clues as to whether there is any evidence of comovement between GDP and GNH in Bhutan.

\section{Figure 3. Bhutan: Real GDP per capita 1980-2017}

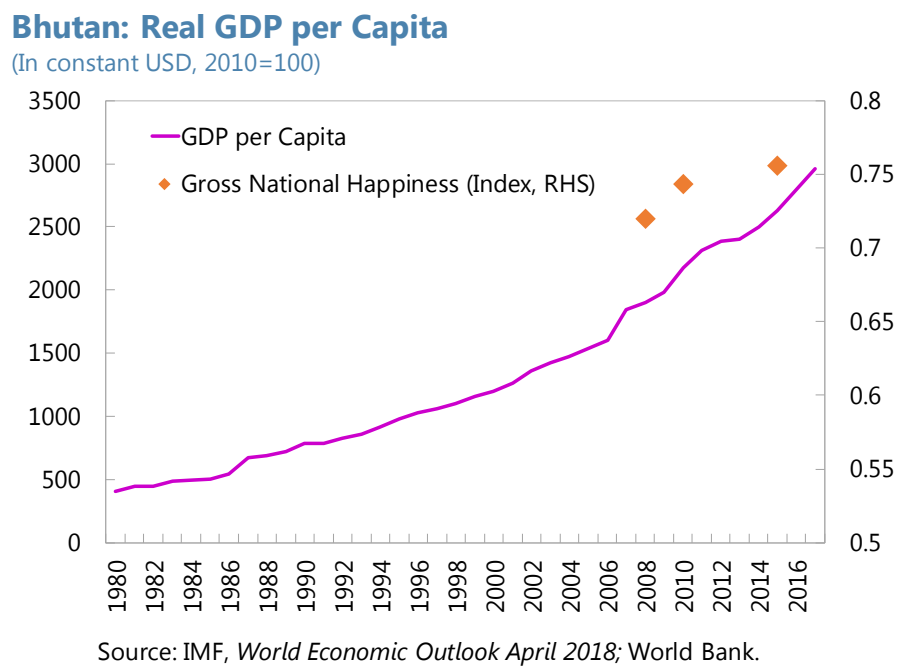

Figure 3 illustrates the changes in Bhutan's real GDP per capita from 1980 until 2017, demonstrating a broad linear increasing trend for real GDP per capita, with per capita income increasing by about six times over this period. It will be important to understand whether there is any demonstrable link between changes in real GDP per capita and key changes in the measurement and policy use of GNH.

\section{Macroeconomic indicators (1980-1990):}

In 1980, real per capita GDP was about US\$400, and started to increase rapidly in subsequent years ${ }^{8}$. According to the Fifth and Sixth FYPs, agriculture and animal husbandry accounted for about half (48\%) of GDP, services contributed $31 \%$, with forestry contributing $15 \%$ of GDP followed by industrial development (power and mining) at $6 \%$ and construction at about $2 \%$ of GDP (see Government of Bhutan, 1980).

The increase in GDP in this decade was largely due to the gradual yet consistent growth in Bhutan's energy sector. This has enabled Bhutan to position itself as a hub of energy exports and in particular enhance its trading relationship with India. About one-fifth of Bhutanese

${ }^{8}$ GDP per capita (constant 2010 U.S. dollars) are from World Bank, World Development Indicators data. 
public and private investment went into energy and power distribution during this decade. Key components of the proposed planned investment, besides energy and power, included industrial development (17\%), agriculture spending (12\%), infrastructure development (11\%), education (8\%) and health (4\%) expenditure (see Government of Bhutan, 1980).

In addition, a large part of its economy was driven by trade and predominantly with India as the key trading partner. According to the World Bank (1988):

"For an economy that nearly 20 years ago functioned largely without trade, Bhutan's present dependence on trade is surprisingly high-imports in 1981/82 amounted to about $40 \%$ of GDP; exports, to about 17\% of GDP. Almost 95\% of the trade is conducted with India, mainly because of Bhutan's landlocked position, but also because a state of free trade exists between the two countries... The largest import categories are machinery and equipment (22\% of estimated imports from India), petroleum products (14\%), metal products $(8 \%)$, foodgrains (6\%), textiles and clothing (6\%), and transport equipment (mainly truck chassis, $5 \%)$.... In 1980/81, Government of India budgetary assistance amounted to 16\% of GDP."

Table 4. Bhutan: GDP Sector Shares and Growth Rates, 1980-89

\begin{tabular}{|l|l|l|l|}
\hline Sector & GDP share 1980 & $\begin{array}{l}\text { Average Growth } \\
(1980-89)\end{array}$ & GDP share 1989 \\
\hline Agriculture & $55.7 \%$ & $5.0 \%$ & $45.1 \%$ \\
\hline Mining \& Quarrying & $0.6 \%$ & $13.8 \%$ & $1.0 \%$ \\
\hline Manufacturing & $3.2 \%$ & $15.2 \%$ & $6.0 \%$ \\
\hline Electricity & $0.2 \%$ & $65.4 \%$ & $10.8 \%$ \\
\hline Construction & $7.8 \%$ & $4.7 \%$ & $6.3 \%$ \\
\hline Trade & $10.9 \%$ & $1.1 \%$ & $6.3 \%$ \\
\hline $\begin{array}{l}\text { Transport \& } \\
\text { Communications }\end{array}$ & $4.3 \%$ & $12.9 \%$ & $6.7 \%$ \\
\hline Financial Services & $6.3 \%$ & $9.8 \%$ & $7.7 \%$ \\
\hline $\begin{array}{l}\text { Community \& Social } \\
\text { Services }\end{array}$ & $10.8 \%$ & $6.8 \%$ & $10.2 \%$ \\
\hline
\end{tabular}

Source: Bhutan Central Statistical Office.

\section{Key GNH-driven themes (1980-1990)}

During this decade there were several key aspects to GNH-based policies, which helped in the achievement of the abovementioned economic growth. These included: a) to achieve an acceptable and sustainable rate of growth of the economy; b) to attain, over time, economic self-reliance and specifically in the Fifth FYP, to attain a level of internal resource generation adequate to cover the normal maintenance expenditure of the government; c) to achieve greater distributional equity among various sectors and regions; and d) to involve the people directly in the planning and execution of development programs. 


\section{Macroeconomic Indicators (1990-2000)}

According to World Bank data from the World Development Indicators database, Bhutan's real GDP per capita in 1990 was about US\$790, and it reached about US\$1220 in 2000. While agriculture had dropped to about 45 percent of GDP in 1989-90, electricity production had increased to over 10 percent of GDP by the end of the decade (see Bhutan Planning Commission, 1990). This indicates a greater inclination towards a more energy-centric evolution of the Bhutanese economy through the years.

The results of the privatization program initiated by the government in the 1980s had its effects in the 1990s, with increasing investment in many areas of the economy by both domestic and external players. The privatization program's key tenets were: a) ensuring the efficient management and operation of enterprises, and thereby promoting economic growth; b) limiting the role of government, so that it can concentrate on activities where there is not an adequate private sector alternative; c) fostering indigenous entrepreneurial and management expertise; and d) providing increased opportunities for saving and investing within the Bhutanese economy.

In addition, the emphasis on the energy sector as a revenue stream for the government increased through the decade of the 1990s, with key inputs provided to the development of these power plants across the country: Gidakom Hydel Station $(1250 \mathrm{~kW})$; Paro Hydel Power House (400 kW); Wangdi Hydel Power House (300 kW); Chhenary Power House (750 kW); Khalanzi Power House (390 kW); Nagu Hydel Power House (50 kW); Lhuntshi Power House (20 kW); and Thimphu Power House (360 kW).

There was also greater implementation of the GNH philosophy in the 1990s, which complemented Bhutan's accelerated real GDP growth. It is also important to note that neighboring countries such as India, which has traditionally been Bhutan's single-largest trading and economic partner, had begun to liberalize and open their energy and product markets to the outside world. A large part of the expansion in this decade was due to the expansion in services and manufacturing sectors, while it should be noted that agriculture and forestry production grew by about 4 percent and the housing sector grew by about 3 percent (see International Monetary Fund, 2018; International Monetary Fund, 2016; International Monetary Fund, 2014).

Total investment (as a share of GDP) in Bhutan has increased from about 35 percent in 1990 to almost 67 percent in 2010 (see IMF World Economic Outlook database and Figure 5 (lower panel)). Note that any dip in investment has been largely in 1997 and 2007-08 - both years when external markets were unstable due to the Asian Economic Crisis and the Global Financial Crisis, respectively. A large part of this investment growth can be attributed to the Government of Bhutan's gradual opening up of the country to private investment, and these policies have boosted growth and overall investment in Bhutan. The privatization program mentioned earlier, which is part of the GNH theme of sustainable private sector development, has also helped support this growth, along with institutional support. 


\section{Key GNH-driven themes (1990-2000)}

During this decade there were several key aspects to GNH-based policies, which helped in the achievement of the abovementioned economic growth. These included: a) self reliance approach to development; b) sustainability, efficiency and development of the private sector; c) people's participation and decentralization; d) human resource development; and e) regionally-balanced development - this includes development of the integrated electricity grid which integrates the Western, Central and Eastern grids - these new power projects are diversified across regions to promote regionally-balanced development strategies. In addition, with the initiation of the privatization drive, The Chhukha Corporation, The Bank of Bhutan, and Druk Air, are three examples of organizations which the government has attempted to privatize over the years.

\section{Macroeconomic indicators $(\mathbf{2 0 0 0}-\mathbf{1 0})$}

Real GDP per capita grew to Nu34,030 (about US\$1220) by 2000 (see Figure 5 (top panel)). Real GDP increased from Nu19.19 billion to Nu43.04 billion over this ten-year period, implying a growth rate of about 124 percent over this period. Growth was driven by significant amounts of external funding which had been provided by international organizations and countries such as India, who have both contributed to the growth of Bhutan over the decades. Alongside this, there was also a GNH-inspired approach to development in Bhutan with a keen focus on decentralization (shifting of resources to dzongkhag and gewogs), capacity development, better communication and coordination, and greater accountability.

According to the Bhutan Planning Commission (2003):

"The Dzongkhag Plan consists of separate Dzongkhag and Gewog programs. Dzongkhag programs will constitute development activities that have relevance to the Dzongkhag as a whole but are not necessarily applicable to a specific Gewog. The Dzongkhag Plan to a large extent includes programs geared towards institutional strengthening and capacity development of their sectoral human resource. Dzongkhag programs also include coordination, supervision and quality control services for Gewogs and inter-Gewog activities along with technical backstopping support, which shall be executed and implemented by the Dzongkhag either independently or jointly with the sectors in the centre."

There was also a substantial effort to boost the private sector through a variety of reforms. This included streamlining of regulatory processes, enabling partnership between finance and private sectors, greater divestment opportunities to make national assets more competitive and productive, and enhanced integration with global financial markets.

The growth of private sector credit (and in turn private investment) in Bhutan over the years 1980 to 2017 is set out in Figure 5 (middle and lower panels). There has been a steady increase in the contribution of domestic credit to the private sector (as a share of GDP) from 31 percent in 1980 to about 50 percent by 2000, and now reaching 65 percent in 2017. It is also interesting to note that while total investment was reduced in 2008 due to the Global Financial Crisis, credit to the private sector seems to have increased during the same 
timeframe in Bhutan. This alludes to either an increase in consumption expenditure by the local population due to an increase in consumer loans or a sustained private sector contribution to investment spending.

\section{Key GNH-driven themes (2000-10)}

During this decade there were several key aspects to GNH-based policies, which helped in he achievement of the abovementioned economic growth. These included: a) creation of the National Environment Protection Act; b) micro-environmental action plans to address biodiversity issues in 950 villages; c) greater access to credit for entrepreneurs in tandem with Bhutan Finance Corporation ; d) enactment of bio-diversity, water policy and food legislation to enable growth; e) promoting industrial development that is sustainable and job centric; and f) World Trade Organization membership and trade liberalization.

During the 2010-17 period, Bhutan's real GDP growth averaged about $63 / 4$ percent, making it one of the fastest-growing low-income countries. Much of that growth has come from the hydropower sector (particularly electricity exports) and from tourism receipts, with fluctuating contributions from construction, mostly related to the building of hydro-related dams (see Figure 4).

Figure 4. Bhutan: Recent Macroeconomic Developments

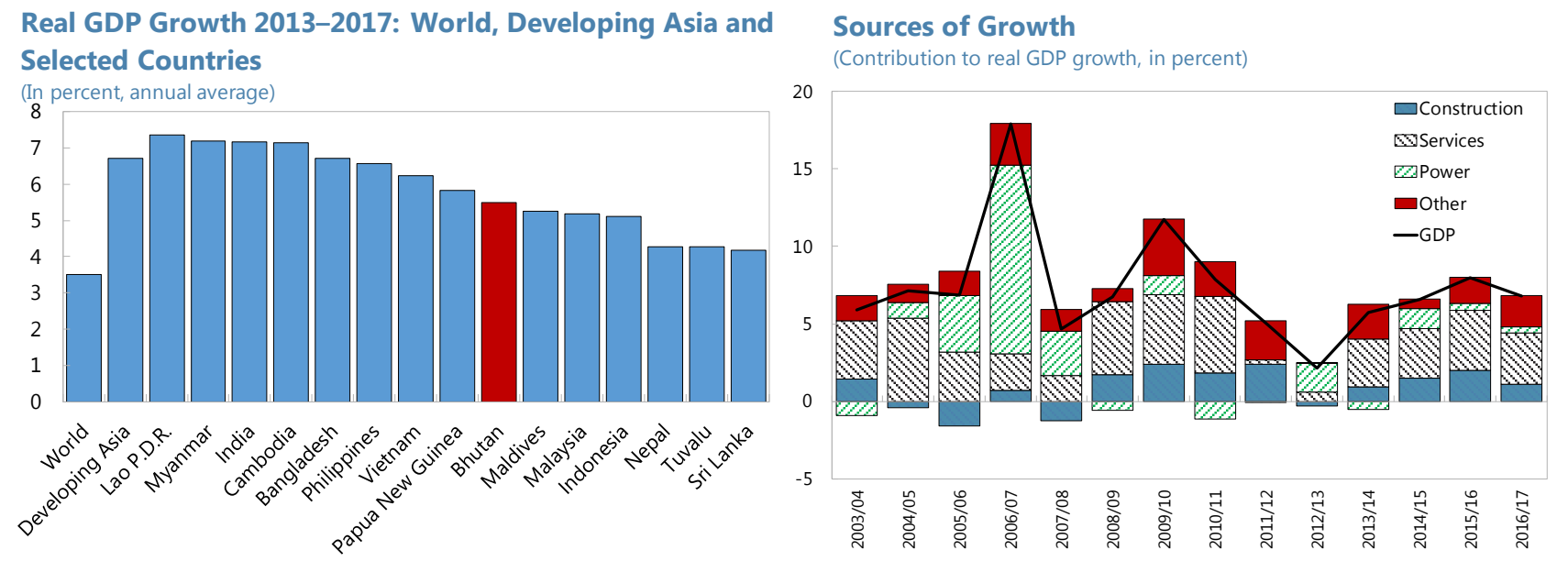

Source: IMF World Economic Outlook.

Sources: Government of Bhutan; IMF staff calculations.

\section{Evaluating Comovement OF GNH AND GDP}

An objective of this paper is to analyze if there is some comovement or causality between GNH and GDP as the two key well-being and macroeconomic measures for Bhutan. This is important as GNH objectives were and are used to guide public policymaking and the allocation of public resources that help to sustain GDP growth. In turn, these increases in real per capita income accompanied improvements in GNH as measured in three discrete GNH 
surveys. Through an analytical process, we have tried to come to a measured understanding of these relationships in Bhutan over the period of time when both GNH and GDP played a significant role in policymaking.

There are several challenges in evaluating links between GNH and GDP, which are as follows:

- The single largest challenge for evaluating comovement of GNH and GDP has been the quality and quantity of available data. While Bhutan has generally produced better data since the turn of the $21^{\text {st }}$ Century, for long periods prior to and after this period, appropriate and good quality data have been challenging to obtain. Additionally, the GNH surveys are limited to three surveys completed over a decade - in 2008, 2010 and 2015 - which limits our ability to have a year-on-year comparison of low frequency GNH with GDP numbers (usually measured at annual frequency).

- The material for secondary research has also been limited because most researchers have looked at the idea of happiness per se, but not really ventured into analyzing the tenets of happiness over such a long period.

- While the various Five-Year Plans have detailed the impact of GNH on policymaking, there are few empirical studies that have evaluated the role of GNH. As such, GNH is the most important aspect of resource allocation and policymaking in Bhutan, yet the least empirically analyzed.

- We also assume that a comparison over a ten-year period from 2005-15 could provide us with a substantive understanding of the broad trends, as the concept of GNH was increasingly incorporated into Bhutan's governance system during that time, along with undertaking the three GNH Surveys.

As shown in Figure 3, real GDP per capita has been increasing on a linear trajectory over a long period of time (particularly during 2005-15), with a mild dip in 2007-08 courtesy of the Global Financial Crisis. On the other hand, as also seen in Figure 3 above, GNH has gradually increased from 0.725 in 2008 to 0.74 in 2010 and to 0.76 in 2015 . This increase has been partly due to additional policy measures taken by the Cabinet and also to a review of the indicators being used in the construction of the GNH index.

Progress in poverty alleviation is one important dimension of GNH that has been recently been evaluated by the Royal Government of Bhutan (see International Monetary Fund, 2018; National Statistics Bureau of Bhutan, 2017). As it concludes the Eleventh FYP in 2018, Bhutan continues to make inroads into reducing poverty at a rapid pace. Key measured developments in Bhutan's poverty trends are:

- Given Bhutan's average GDP growth of $7 \frac{1}{2}$ percent over the decade to 2017 , driven in large part by hydropower construction and exports, the poverty rate in Bhutan has declined from 23.2 percent in 2007, to 12 percent in 2012, and further to 8.2 percent in 2017. Poverty reduction was a key focus of the Tenth FYP (2008-13), the period 
corresponding to the steepest decline in poverty, with further reduction in poverty and improved social outcomes observed during the Eleventh FYP.

- While poverty in Bhutan is largely a rural phenomenon, impressive gains have been made in reducing rural poverty from nearly 31 percent in 2007 to 16.7 percent in 2012 and about 12 percent in 2017, whereas urban poverty has also declined from very low initial levels (1.7 percent in 2007) to 0.7 percent in 2017.

- Available statistics on access to public services and information are also encouraging. The population is reported to have almost universal access (around 99 percent) to improved water sources, with no significant differences across income groups. At least 92 percent of households have access to improved sanitation, with only an eight percent difference between poor and non-poor households.

Analysis of the main drivers of the rapid change in poverty suggests that an increase in nonfood consumption has been the main driver, with little change occuring in food consumption patterns (see International Monetary Fund, 2018). No doubt this much-diminished level of rural and urban poverty will be reflected in the overall GNH index arising from the next GNH survey whose details are yet to be announced by the government.

\section{CONCLUSION}

Following an examination of the construction and survey design for measuring GNH, in this paper we then looked at whether there is evidence of comovement between the Bhutanese concept of GNH and other macroeconomic-developmental indicators such as GDP. The observations and conclusions from the above mentioned information are as follows:

- Given the paucity of time series of GNH observations, and notwithstanding the implications of the Easterlin Paradox, there has been an association between rising GNH and the broader growth story of Bhutan, as measured in increasing real GDP, real per capita GDP, and growing poverty alleviation. This period of rising real incomes also corresponds with the increasing influence of GNH in public policymaking in Bhutan.

- Besides this quantitative approach, interactions with a variety of Bhutanese stakeholders through formal and informal discussions indicate that the concept and measurement of GNH, notwithstanding its drawbacks, has played a part in enabling Bhutan's macroeconomic indicators to grow in a more sustainable manner (see Columbia University, 2016). The evolution of GNH highlights that some key GNH schemes have been integrated into the Five-Year Plans of Bhutan, which in turn have helped raise the economic growth of Bhutan.

- Nonetheless, measurement of GNH has its own share of drawbacks, including: the high level of subjectivity involved in its measurement; and involvement of an elaborate set of GNH indicators which can be time-consuming to evaluate. 
- Other more open and larger countries have much more complex economic systems than Bhutan. Nonetheless, it is important to acknowledge the usefulness of indicators such as GNH as a complementary measure to other macroeconomic indicators, to help ensure that individual national growth models are sustainable and relevant to the socio-cultural norms of each country. Finally, it is important for Bhutan to undertake more frequent GNH surveys and evaluations, to better build evidence for the comovement of Gross National Happiness and macroeconomic concepts such as Gross Domestic Product. 


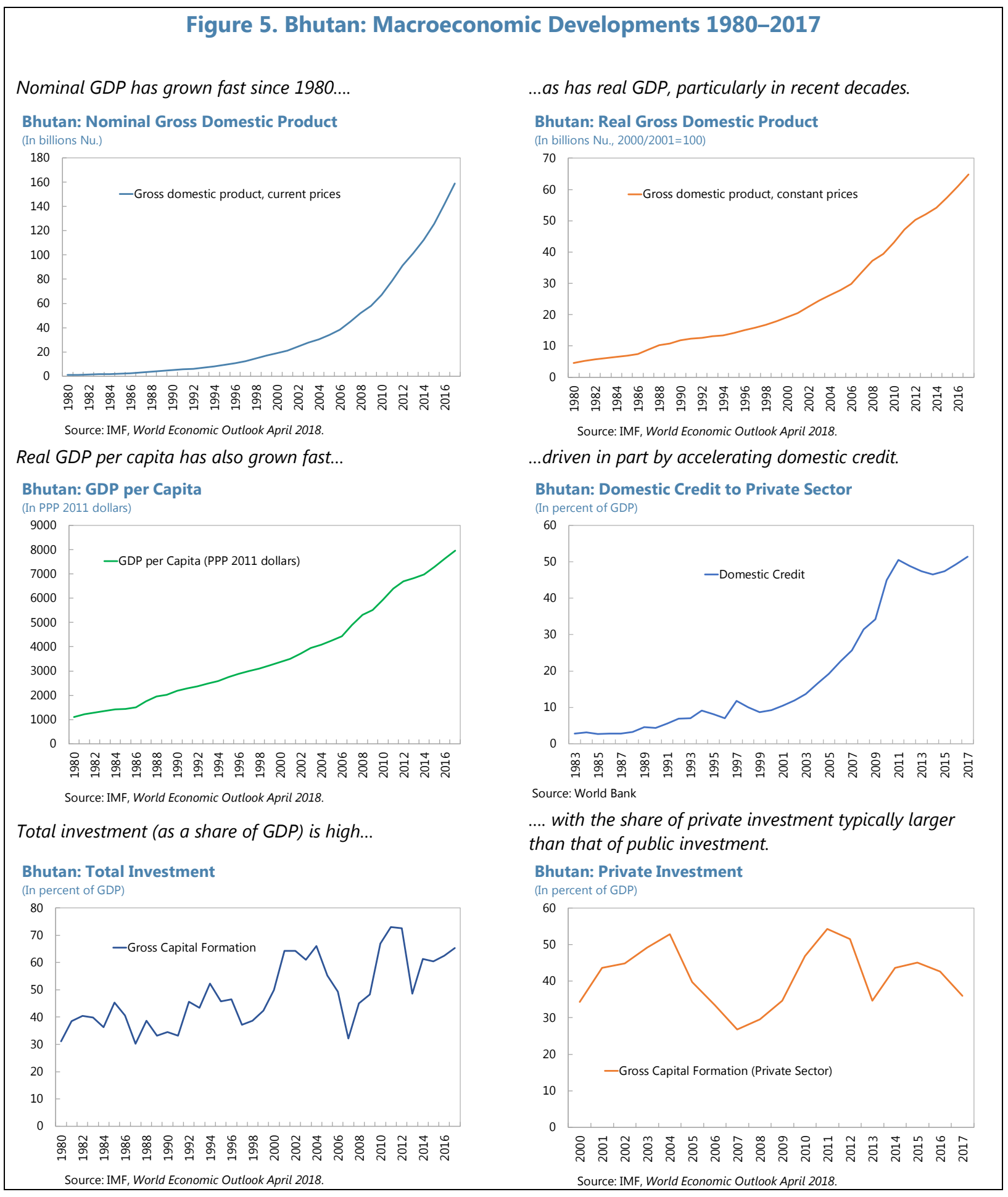

CInternational Monetary Fund. Not for Redistribution 


\section{References}

Bhutan Planning Commission (1990). Seventh and Eighth Five-Year Plans. Thimphu: Government of Bhutan.

Centre for Bhutan Studies and GNH Research (2016). A Compass Towards a Just and Harmonious Society: 2015 GNH Survey Report. Government of Bhutan: Thimphu.

Clark, Andrew E. and Claudia Senik (2011). Will GDP Growth Increase Happiness in Developing Countries? Discussion Paper No. 5595. Bonn: IZA.

Columbia University (2016). Translating Gross National Happiness into Practice: Bhutan's Approach. School of International Public Affairs, Columbia University: New York City.

Dorji, Dasho R. (1991). A Brief Historical Background of Religious Institutions of Bhutan. Buddhist Himalaya: A Journal of Nagarjuna Institute of Exact Methods, Vol. III No. I \& II (1990-1991). Nagarjuna Institute of Exact Methods.

Easterlin, Richard A. (1974). "Does Economic Growth Improve the Human Lot?" in Nations and Households in Economic Growth. Editors: P.A. David and W.B. Melvin. Palo Alto, Stanford University Press: pp. 89-125.

Easterlin, Richard A. (1995). "Will Raising the Incomes of All Increase the Happiness of All?" Journal of Economic Behavior and Organization, Vol. 27, pp. 35-47.

Government of Bhutan (1980). Fifth and Sixth Five-Year Plans. Thimphu: Government of Bhutan.

Government of Bhutan (2003). Ninth Five-Year Plan. Thimphu: Government of Bhutan.

Government of Bhutan (2010). Gross National Happiness Survey 2010. Government of Bhutan: Thimphu.

Government of Bhutan (2015). The Story of Gross National Happiness. Thimphu: Government of Bhutan.

Gross National Happiness Commission (2018). Eleventh Five-Year Plan 2013-18: Self Reliance and Inclusive Green Socio-economic Development, Final Report. Royal Government of Bhutan: Thimphu.

Helliwell, John F., Richard Layard, and Jeffrey D. Sachs (2018). World Happiness Report 2018, New York: Sustainable Development Solutions Network.

International Monetary Fund (2007). Bhutan 2007 Article IV Consultation: Staff Report, IMF Country Report 07/350, International Monetary Fund: Washington DC. 
International Monetary Fund (2009). Bhutan 2009 Article IV Consultation: Staff Report, IMF Country Report 09/334, International Monetary Fund: Washington DC.

International Monetary Fund (2011). Bhutan 2011 Article IV Consultation: Staff Report, IMF Country Report 11/123, International Monetary Fund: Washington DC.

International Monetary Fund (2014). Bhutan 2014 Article IV Consultation: Staff Report, IMF Country Report 14/178, International Monetary Fund: Washington DC.

International Monetary Fund (2016). Bhutan 2016 Article IV Consultation: Staff Report, IMF Country Report 16/206, International Monetary Fund: Washington DC.

International Monetary Fund (2018). Bhutan 2018 Article IV Consultation: Staff Report, IMF Country Report 18/300, International Monetary Fund: Washington DC.

National Statistics Bureau of Bhutan (2017). Bhutan Poverty Analysis Report 2017. Royal Government of Bhutan: Thimphu.

National Statistics Bureau of Bhutan (2018). Population and Housing Census of Bhutan: National Report. Royal Government of Bhutan: Thimphu.

United Nations Development Program (2015). Human Development Index. United Nations: New York City.

World Bank (1988). World Development Report. Washington DC: World Bank. 